27 Ibid, 257.

28 Throughout his career, Kemp defined his clown as a 'plain man'. See Wiles, Shakespeare's Clown, 100.

29 Orgel, The Authentic Shakespeare, 22.

30 John Lyly, Euphues, the Anatomie of Wit (1578), The Complete Works of John Lyly, R.W. Bond (ed.), 3 vols (Oxford, 1902), 1.180.

31 Robert Weimann, Author's Pen and Actor's Voice: Playing and Writing in Shakespeare's Theatre (Cambridge, 2000), 23.

32 John Lyly, Midas (1589), The Complete Works, Bond (ed.), 3.115.

33 Arthur Brooke, The Tragicall Historye of Romeus and Juliet, 1562 (1l.161-2), reproduced in William Shakespeare, Romeo and Juliet, ed. Brian Gibbons (London, 1980), 244.

34 Frank Kermode, Shakespeare's Language (London, 2001), 34.

\title{
Actor, Poet, Playwright, Sharer ... Rival? Shakespeare and Heywood, 1603-4
}

A person ... competing with another for the same objective, or for

superiority in the same field of activity.

A person who ... is arguably equal in quality or distinction to another.

A person having the same objective as another, an associate.

$\left(O E D \text { : 'Rival', n. }{ }^{2} 1-3 \text { : Range of definitions valid in } 1603-4\right)^{1}$

An actor, poet, playwright, and sharer. A country boy, whose family acquired a grant of arms around the turn of the century giving him the right to be addressed as 'gentleman', he came to London in the early 1590 s and gained work as an actor and a reputation as a playwright. In 1598 Francis Meres lauded him as among 'the best for comedy'. He was among those who contributed additions and alterations to Munday's Book of Sir Thomas More after Tilney censored it. In 1612 Webster praised his 'right happy and copious industry'. He was strongly influenced by Ovid and took great care over the publication of his poetry; however, he seems to have made little effort to see his plays through the press. After learning his craft through acting and writing for various groups he accepted the opportunity to become a sharer at the establishment of a prestigious new company to which he committed himself 
for well over a decade, writing for actors whose strengths he knew and who were long-term colleagues and friends.

His work was also popular at court: at least one of his plays was re-presented within days by royal command. The company to which he belonged acquired royal patronage on the ascent of James I to the throne. Consequently he was given a grant of cloth and walked (at least theoretically) in the procession marking the king's official entry into London in 1604; as grooms of the royal household he and his fellows were required to wait upon visiting foreign dignitaries later the same year.

All of the above applies to Shakespeare. It also applies to Thomas Heywood. $^{2}$ I could add more. Obviously differences also hold true. Heywood was both more elite in his classical learning and Cambridge education and more populist in his enduring enthusiasm for the clown role; Shakespeare was the senior by about nine years and always the more established, having started his theatrical and literary career several years earlier. Yet in many ways the two men's professional and personal lives mirror each other.

Scholars have paid considerable attention over the centuries to the so-called 'War of the Theatres' at the end of Elizabeth's reign - an exchange more accurately described by Dekker's mock-heroic term from Satiromastix as a 'Poetomachia' or 'war of the poets. ${ }^{3}$ This overt flyting, mainly by the flashier emergent dramatists Marston and Jonson with their intellectual aspirations, has obscured any quieter rivalry between the two more established commercially-focused playwrights. The long-standing critical belief in the hostility between the adult groups and the new boy companies has exacerbated this blindness, while more recently Andrew Gurr's emphasis on what he calls the 'duopoly' of the Chamberlain's and Admiral's Men has concentrated discussion on these two companies as the relevant opposites of the time, diverting attention away from any alternatives. The respective allegiances of the two main Elizabethan star actors, Alleyn and Burbage, reinforce this binary reading. Too often, scholars forget that this situation reflects only one period within Shakespeare's career, and that the early seventeenth-century theatre context was very different. In the same way, the prominence of the Globe continually overshadows the diverse theatre spaces for which Shakespeare wrote. I suggest that the parallel careers and frequently similar artistic priorities of Shakespeare and Heywood deserve factoring into the picture.

Heywood has alternately been maligned and ignored by posterity. Many of his plays were collaborations; no collected folio of his dramatic works was printed; his theatrical focus seems to have been on practical dramaturgy 
rather than linguistic elegance - all characteristics traditionally unlikely to appeal to literary critics. Whereas Shakespeare's multiple responsibilities and varied types of artistic output have enhanced his creative reputation, in Heywood's case this diversification has served only to confirm his apparent hack status.

We should not, however, project the verdict of later generations backwards onto Heywood's contemporaries. The dramatist was a considerable success in his own lifetime, claiming to have had 'either an entire hand, or at the least a maine finger' in 220 plays. ${ }^{4}$ Despite Heywood's professed lack of interest in having them printed, Lukas Erne's calculations indicate that 'for the whole period from the beginning of the publication of professional plays to $1642 \ldots$ the second most published playwright [after Shakespeare] is not Jonson ... nor Middleton ... nor Beaumont or Fletcher ... but Thomas Heywood', while, as Muriel Bradbrook remarks, his non-dramatic publications (even without the influential 1612 Apology for Actors) 'far outmeasure the printed remains of Shakespeare and Jonson combined'. 5 As a practical man of the theatre himself, Shakespeare must have admired Heywood's skill and expertise, as well as his professional success and longevity. Indeed, he may even have seen him as a potential threat, especially on his elevation to sharer in the suddenly up-and-coming Worcester's Men.

The main thrust of my paper focuses on this moment at the start of the seventeenth century. According to critical commonplace Heywood drew repeatedly on Shakespeare. I argue that in one significant instance at least the influence ran in the other direction. This article starts by outlining the context in which Heywood wrote $A$ Woman Killed with Kindness. I then argue in some detail for the play's influence on Shakespeare's Measure for Measure, a connection which critics and editors have so far disregarded. We are fortunate in having very secure dating for Woman Killed (discussed below); the slightly later composition date for Measure, though less precise, has never seriously been in doubt - it is consistently assigned to mid-1603 to mid-1604, with a performance at court on 26 December 1604 providing a terminus ad quem. ${ }^{6}$

If space had permitted, I would have ended with a brief coda re-examining a single moment of tension in 1612, when Jaggard included poems by Heywood under Shakespeare's name in a reprint of The Passionate Pilgrim - the one moment for which we have evidence of interaction between the two men. In the circumstances, however, I shall leave that thought hanging as a trailer for a future article since, while both men appear to have 
taken action to protect their reputations, they did so in a literary rather than a dramatic context.

The turn of the century saw a series of realignments in the London theatre scene. In 1599 the Lord Chamberlain's Men successfully launched their new playhouse, the Globe, on the south bank of the Thames, only yards from the Admiral's Men's Rose Theatre. Within a year their 'opposites' had moved to their own state-of-the-art theatre, the Fortune, on the other side of the city, leaving the Rose without permanent residents. Meanwhile Derby's Men had been trying out the Boar's Head as a London home and the re-emerging boyplayer troupes were contributing another complicating factor. In 1601 a further adult company joined the mix. The Earl of Worcester, newly in favour at court, took the opportunity to enhance his status by merging the company touring under his name with the recently revived Oxford's Men and bringing them to the capital; within months they had performed before the queen and obtained official permission to establish themselves in a London venue. ${ }^{7}$ This new grouping included strong actors past and future (amongst them the ex-Chamberlain's Men clown, Will Kemp, and John Lowin, soon to become a central figure in the King's Men) and swiftly attracted the services of experienced dramatists such as Chettle, Dekker, and Munday, plus the skills of the entrepreneur Henslowe to manage their financial outgoings. ${ }^{8}$ It also numbered among the sharers one Thomas Heywood. ${ }^{?}$

In August 1602 Worcester's Men took over the empty Rose. Their initial expenditure here was substantial, with significant emphasis on costume and spectacle: they were obviously attempting both to make a mark and to invest for the long term. ${ }^{10}$ One of the very first actions they took when transferring to their new home (even before the official confirmation of their 'a grement' with Henslowe) was to acquire the rights to the Admiral's Men Oldcastle and commission new additions. ${ }^{11}$ Given that Oldcastle, when first performed, explicitly positioned itself as a riposte to the presentation of Falstaff in Henry $I V$ - 'It is no pamperd glutton we present, / Nor aged Councellor to youthfull sinne' Prologue 6-7 - it seems legitimate to interpret the revival either as a gesture of defiance to the company's more established Bankside neighbours or, at the very least, an attempt to exploit the success of some of the plays in their repertory. ${ }^{12}$ In view of this situation, I suggest that Shakespeare inevitably would have kept a careful eye on not just the company but more specifically (and perhaps more personally) on this new phenomenon of another actor/sharer/playwright suddenly plying his trade right on the doorstep. One play in particular seems to have caught his attention. 
We have considerable documentary evidence for the development, dating, and impact of Heywood's A Woman Killed with Kindness. Henslowe's Diary indicates that the play was completed and delivered by 5 March 1603; the final costume payment was made on 7 March, the day the London playhouses theoretically closed for Lent. Within days Henslowe had summed the company's accounts for the period and Worcester's Men had set out on tour, presumably intending to perform Heywood's play in the provinces once licensed and present it in the capital after Easter. The queen's imminent death, however, led to formal closure of the playhouses on 19 March. Although scholars repeatedly assume performances in March (and even February) the play's London première actually occurred in a very different context: Worcester's Men recommenced playing at the Rose on 9 May; later that month the theatres closed due to plague until the following April. ${ }^{13}$ Woman Killed was therefore one of the last plays to launch before the closure.

It appears to have been an instant and memorable success. The original production was lavish, even by the standards of Worcester's Men. ${ }^{14}$ The much-quoted entry of $£ 613$ s. for 'A womones gowne of black velluett for the playe of A womon kylld $\mathrm{w}^{\text {th }}$ kyndnes' is the most expensive single item in the company's nine months' accounts - and (though this seems to have gone hitherto unremarked) this expenditure is for just one of several outfits for Anne, who starts the play in a wedding dress and appears in two key scenes in her 'night attire' (13.78.sd, 17.38.sd). ${ }^{15}$ This gown alone cost almost double the $£ 39$ s. paid out on The Play of the Two Brothers, which was enough to cover raw materials for 'devells sewtes', 'a wiches gowne', 'a tabell \& a coffen', plus a craftsman to paint the 'properties' and a 'tyer man' to make the costumes. ${ }^{16}$

Moreover, as I shall argue below, both main plot and sub-plot were sensationalist. Despite the play's brief initial exposure and the subsequent ten month lapse, Middleton felt able to refer to it in his March 1604 satirical pamphlet, The Black Book, in the confidence that his readers would pick up the reference and remember the story's outcome; the title was namechecked repeatedly in subsequent work by Dekker, Fletcher, and Heywood himself; the play continued in the repertoire after Worcester's Men became the Queen's Men the following spring; it went through three editions by 1617, and the 1607 quarto was the first play to include Heywood's name on the title page. Either he had reasons to claim it or his name suddenly had pulling-power. ${ }^{17}$ 
A Woman Killed with Kindness was thus one of London's most recent and most striking new plays when Shakespeare started work on Measure for Measure (probably during the plague closure) and was presumably staged contemporaneously with it when the theatres finally reopened the following year. ${ }^{18}$ Given the play's apparently high profile, a lack of response from the King's Men would have been strange in an environment in which sequels and alternative treatments of material were all the rage. (Measure also offers visual echoes of the other current hit which Middleton bracketed with Woman Killed - The Merry Devil of Edmonton, in which a novice is liberated from a nunnery by a disguised 'friar' whom she then marries. These echoes are perhaps no coincidence.) Heywood's choice of title even seems to throw down a personal challenge to Shakespeare, who may himself have coined this permutation of the proverb, using it prominently and provocatively in The Taming of the Shrew: 'This is a way to kill a wife with kindness' (4.1.194). ${ }^{19}$

Shakespeare could hardly have avoided hearing details of Heywood's play. I suggest that he could well have seen it. In A Cure For a Cuckold (1624) the character Compass claims rights in the son conceived in his absence by analogy to the 'Law amongst the Players [by which] a fellow shall have his share though he do not play that day' (D1); T.J. King's work on actor-character break-downs and company documents from the early Stuart years leads by a separate route to the conclusion that 'every member of the company [did] not act in every play'; the lists of performers that Ben Jonson attached to his early plays suggest that this practice was also standard in the late Elizabethan period. ${ }^{20}$ Certainly Jonson's catalogues of names establish that while Shakespeare played in both Every Man In His Humour and Sejanus, he did not act in Every Man Out of His Humour. He clearly therefore had the opportunity at least occasionally to observe other playwrights' work. Given the extent to which companies and dramatists responded to one another's repertoires in this period (and the speed with which they did so - this is a reaction to performance, not publication) we can justifiably assume that the Chamberlain's Men and Shakespeare himself would have been keen to enable and take advantage of such opportunities.

At least three overlapping aspects of $A$ Woman Killed with Kindness could have provided stimuli for Shakespeare when he was writing Measure for Measure. The plays have close thematic links, both concerned primarily with how to respond appropriately to sexual transgression, Heywood focusing on the head of the household, Shakespeare on the head of the state. Both additionally use subordinate narratives to pull in further aspects of the law and throughout 
explore concepts of justice and mercy, punishment and forgiveness. Alongside these concerns runs the secondary theme of substitution, the interchangeability of one person for another, the exchange value of different types of commodity or moral worth, the balancing of one thing by another. ${ }^{21}$

Second, and more unusually, both plays are structured firmly on central brother/sister pairs, a relationship type which barely features in sixteenthcentury drama but suddenly starts to come into focus around 1600. This dynamic raises questions about family, power, and sexual control very different from those enabled by the parent/child structure previously typical of comedy, and it opens up a new field of exploration for the dramatists. More significantly, in both plays a brother requests that his sister sacrifice her chastity in exchange for his rescue from jail. Whereas traditionally society would have demanded that a man sacrifice his life or freedom for his sister's honour, these plays provocatively reverse the moral responsibility. These two versions of the 'monstrous ransom' motif (the first on the commercial stage) provide a stepping-stone in the transition to the Jacobean stage brother prepared to pimp for his sister or commit incest with her.

Finally, both plays push the audience to re-examine current and traditional moral, social, and religious values, offering controversial choices and challenging debate and disagreement. Both present us with final outcomes that have the potential to leave modern audiences disturbed rather than reassured or exhilarated. Critics often consider this effect to be a simple disjunction between modern and early modern expectations and sensibilities. Writing on Woman Killed in 1951 Peter Ure commented mockingly, 'Heywood was not writing a problem play' and as recently as 2009 Gurr could dismiss the tragedy casually as 'conventionally moralistic.' ${ }^{22}$ Yet Heywood repeatedly and clearly opts to problematize his source material and place it in a more challenging moral framework, as Richard Rowland and Jennifer Panek have both argued cogently and in detail. ${ }^{23}$ Importantly, the ambivalent title and the resolution which embodies it are entirely Heywood's own contribution to the adultery dilemma. Frankford's cold and considered psychological approach to revenge combined with the ambiguous and repeated application of the old proverb surely provoked debate as to whether his action was primarily an act of 'kindness' or of 'killing'. Certainly Middleton's interpretation seems closer to modern readings than to those projected backwards onto the early modern: his reference in The Black Book mentioned above alludes to a typical adulterous wife despatching her chaperoning servant to the theatre to see $A$ Woman Killed with Kindness while continuing alone to an assignation that will bring upon her 'the 
same murther' (C3). I suggest that both main and sub-plots deliberately challenged the audience and that this, like Measure, was indeed a 'problem play'.

A brief review of the plot of $A$ Woman Killed with Kindness with these issues and the Measure parallels in mind may be useful. (Shakespeare's play needs no repetition here.) The sibling relationship of Anne and Acton links the play's two narratives, while the brother/sister bond between Charles and Susan dominates the subplot. Heywood opens with the marriage of Anne Acton to John Frankford. Subsequently Frankford invites one of the guests to stay on indefinitely, offering him 'Your man, your gelding, and your table, / All at my own charge' and entreating him 'to make bold ... and command', 'be a present Frankford in [my] absence' (4.71-2, 6.75, 78). Wendoll takes this invitation rather too literally, replacing Frankford in his bed as well, though he prefaces his attempt on Anne's virtue with a soul-searching soliloquy, realizing his action will make him 'damned without redemption' (6.3). Like Angelo at the same point (2.4.1-4), Wendoll has recourse to prayer, but with similar lack of success:

I'll pray and see if God within my heart
Plant better thoughts. Why, prayers are meditations,
And when I meditate - O God forgive me -
It is on her divine perfections.

Alerted by a servant, Frankford fabricates a departure and returns to catch the guilty pair in flagrante. His impulse to violence in the heat of the moment is stayed by a maidservant and he allows Wendoll to escape. As for Anne, after a brief withdrawal to consider her 'sentence' (13.132) he resolves to 'torment [her] soul, / And kill [her], even with kindness' (156-7); her overt punishment is simply to be cut out of his life, banished to a nearby manor. In response, Anne starves herself to death in an attempt to atone and to regain her honour; she is finally reconciled with her husband in a deathbed remarriage surrounded, as in the opening wedding celebrations, by servants and family.

The sub-plot is more complicated, both morally and in terms of plot twists. Since Arthur Melville Clark's oft-quoted comment 'We endure it, but its details escape the memory' still holds true for many, it is worth summarizing in more detail. ${ }^{24}$ At the wedding party Anne's brother, Sir Francis Acton, challenges a fellow knight to a hunting wager. A fight over the outcome ensues, and Sir Charles kills two of Sir Francis's servants. Having spent his fortune in legal fees to gain an acquittal, he encounters a friendly 
neighbour who offers to loan him money. This neighbour, however, has an ulterior motive: he promptly tries to force Charles to sell his remaining ancestral property. When Sir Charles refuses to part with 'this virgin title never yet deflowered' (7.23), he is thrown back in jail for being unable to repay the loan. He sends his sister to try to raise money from their relatives, only to find '[their] kindred with [their] plenty died' (10.70): Susan's eloquence, like Isabella's, is insufficient on its own to ransom him.

Sir Francis, however, has since noticed her and attempted, repeatedly and unsuccessfully, to seduce her, originally as an additional affront to Charles, but then genuinely affected by 'her divine and chaste perfections' (9.61). Since Susan rejects all letters and presents he decides to 'fasten ... a kindness on her' (66) by paying Charles's debt. When Charles realizes whose money has ransomed him, he tries to return to jail but is refused admittance. He can think of no way to recover his honour and repay his enemy, until Susan confesses that Sir Francis has been pursuing her, and would willingly pay 'a thousand pound' 'might he enjoy [her] bed' $(14.43,42)$. Charles's debt is only $£ 500$. In an agonized scene he persuades his sister to lay down her chastity to redeem his honour, and offers her to Acton as repayment for the 'kindness [which] like a burden hath surcharged' him (63).

In the Italianate source-story the feud between the families is ancestral not personal, and love and nobility motivate the behaviour of the Acton equivalent throughout. The brother and sister base their actions on the explicit gamble that he will prove too generous to take advantage of the woman. ${ }^{25}$ Heywood's characters have no such expectations: Charles's approach is aggressive, rather than conciliatory, and he is fully aware of the realities of the situation: 'Acton, she is too poor to be thy bride; / And I too much opposed to be thy brother' (124-5). Both siblings are prepared to save Charles's honour by the surrender of Susan, but then to kill themselves once Acton has consummated his bargain. Acton's 'stern heart', however, 'relent[s]'; overwhelmed by this 'honourable wrested courtesy' $(118,121)$ he offers marriage and friendship, creating new bonds of kinship: 'I seal you my dear brother, her my wife', 'Blest only in our brother and fair bride' $(146,156)$. The play ends with the sibling bonds reemphasized as the three families join together at Anne's deathbed and Acton explicitly reforges his fraternal link with Frankford (17.101-4, 130-5).

Obvious similarities exist between the Charles-Susan-Acton plot and the Claudio-Isabella-Angelo stand-off; rather more subtle parallels link the triangle of Vincentio, Angelo, and Isabella with that of Frankford, Wendoll, and Anne. Frankford's determination in Woman Killed 'to try two seeming 
angels' (11.2) sums up precisely what many see as Vincentio's purpose in Measure, deliberately testing first Angelo and then Isabella. In the main plot Wendoll substitutes for Frankford domestically, personally, and then sexually, becoming the 'present Frankford' he is invited to be (6.78), his 'self' (8.212). This merging of selves is both sealed by the sharing of the woman, as so often in the male friendship trope, but also destroyed by it; the 'bad trick' (180) which Wendoll plays Frankford finds an echo in the bed-trick which Isabella and Mariana play Angelo, and also in the ways in which Angelo and Vincentio share a single persona, a desire for Isabella, and a willingness to use Claudio as a lever.

The two women face very similar choices. In Heywood's play, Susan is presented with a fait accompli since her brother has already been released. The suggestion, moreover, that she offer her body to cancel his debt of honour, the joint family debt, comes from Charles himself. Having already received the benefit, she sees no option but consent followed by suicide. Once offered marriage she again sees no choice but to accept the man she has known as 'Acton, that seeks our blood!' (7.95) and 'learn to love where I till now did hate' (14.148). In contrast, Isabella is initially offered a more open choice, since her brother is still under threat, but here the stakes are higher: the price is Claudio's life, rather than his honour — indeed, Shakespeare suggests that he will lose rather than redeem his honour if she submits. The machinations of the Duke enable Isabella to evade this decision at first by agreeing verbally but getting another to deliver on her promise. In the final act, however, Isabella faces the decision yet again and from a very different quarter; this time her dilemma is very similar to Susan's quandary. The Duke unexpectedly reveals that he has succeeded in saving her brother after all and in the next sentence requests Isabella's hand. The phrasing and juxtapositions imply that her self-surrender in marriage is a reasonable exchange for Claudio's life and pardon, and also, as in the earlier play, underline the new fraternal link that the woman's acquiescence enables:

If he be like your brother, for his sake

Is he pardoned; and for your lovely sake

Give me your hand, and say you will be mine.

He is my brother too.

Like Susan, Isabella has been put in a virtually impossible situation, overcharged with kindness. The Duke's swift change of tack — 'But fitter time 
for that' 5.1.492 - clearly suggests an initial lack of response; whether his second unanswered proposal forty-one lines later is any more successful the play notoriously leaves open.

I do not wish to deny the contribution of George Whetstone's apparently unperformed Promos and Cassandra (1578) or Cinthio's much reprinted but never 'Englished' 1565 novella collection Hecatommithi as source material for the 'monstrous ransom' strand of Shakespeare's play. I do suggest, however, that Woman Killed was the theatrical trigger that sent him back to re-read these early Elizabethan print texts. Similarly, I am happy to acknowledge James I's fascination with the concept of mercy. Yet Woman Killed reminds us that this issue was already theatrically topical before the announcement of his succession. Lastly, interpreting either Shakespeare's tragicomedy or Heywood's domestic tragedy as a deliberately problematic play in its own time allows us more easily to see the other in the same way.

The interconnections between these plays and playwrights deserve far more detailed elaboration than space allows for here. I would like to close on three points.

First, by 1604 A Woman Killed with Kindness and Measure for Measure were playing at the same time and to essentially the same audiences, offering theatregoers a chance to see the resident dramatists for the newly elevated King's and Queen's Men producing contrasting explorations of topical themes and motifs. Whatever Shakespeare's intentions or influences, many must have experienced the two plays in the context of each other. I suggest that to do so can be as stimulating an experience for us as for them. Considering these plays in conjunction enhances our appreciation of both and broadens our understanding of early modern attitudes to the issues they raise.

Second, I am not proposing a cut-throat rivalry here, not even something as self-consciously portentous as a 'sharer-machia' or 'skirmish of the sharers'. However, just as Roslyn Knutson envisages the Chamberlain's and Admiral's Men going 'toe to toe across Maid Lane', exercising 'competition through similarity', so we can see Shakespeare and Heywood as a balanced pair of 'rivales', drawing on the $O E D$ Latin etymology: 'person[s] on the opposite bank of a stream from [one] another [be it the gutter down Maiden Lane in 1602-3 or the Thames from 1604 onwards] ... in pursuit of the same object', keeping a watchful eye on each other's activity and willing to respond. ${ }^{26}$

Finally, I suggest that Heywood's role and status in the early modern theatre has been significantly overlooked and is due for serious re-evaluation. Richard Rowland's work over recent years has started this process. ${ }^{27}$ 
Changing attitudes to collaboration, an increasing emphasis on repertory studies, and a new appreciation of dramaturgical skill are creating a climate which should facilitate its continuation. ${ }^{28}$ Shakespeare did not ignore Heywood; neither should we.

Clare Smout

\section{Notes}

The original version of this paper was written for the seminar 'Locating Early Modern Repertories', chaired by Tom Rutter, at the British Shakespeare Association Conference 2009. I am grateful for the detailed feedback from fellow participants Bart van Es, Charles Cathcart, and Warren Chernaik, and to Tom Rutter for his helpful comments and unfailing patience. I am also indebted to the generosity of Richard Rowland, who gave me advance sight of his monograph Thomas Heywood's Theatre, 1599-1639: Locations, Translations, and Conflict (Aldershot, 2010).

Quotations from Shakespeare refer to Stanley Wells et al. (eds), William Shakespeare: The Complete Works, 2nd edn (Oxford, 2005). Quotations from Thomas Heywood's A Woman Killed with Kindness refer to Brian Scobie (ed.), (London, 1985); this edition uses scene but not act divisions. The place of publication for all early modern printed material is London.

Finally, I have deliberately avoided opening up discussion of potential influence from Woman Killed on Othello, partly due to word constraints but mainly because current thinking, as embodied in the most recent leading editions by E.A.J. Honigmann (Walton-on-Thames, 1997), 344-50 and Michael Neill (Oxford, 2006), 399-404, dates Othello to 1601-2 and 1602-3 respectively, rather than the traditional 1603-4. A nexus clearly exists between these three plays, but one which needs a longer article than this to do it justice.

1 Roslyn Lander Knutson, Playing Companies and Commerce in Shakespeare's Time (Cambridge, 2001), 125-6, usefully initiated debate on the early modern usage of 'rival'.

2 This note provides full references for the data on Heywood's life, but only selected references to the Shakespearean material which is mainly familiar and available in the public domain in multiple places. The quotations from Francis Meres, Palladis Tamia (1598), Oo3v, and John Webster, Prologue to The White Devil (1612), A2v, reference both Shakespeare and Heywood. The most recent discussions of the 'hands' and dating for Munday's The Book of Sir Thomas More are still those in 
T.H. Howard-Hill (ed.), Shakespeare and Sir Thomas More: Essays on the Play and its Shakespearian Interest (Cambridge, 1989), and the edition by Vittorio Gabrieli and Giorgio Melchiori (Manchester, 1990); John Jowett's forthcoming edition for the Arden Early Modern Drama series may open up new arguments. Heywood is usually considered to be 'Hand B', Shakespeare 'Hand D'; however, the two were working at separate stages and the later hand (D) was unaware of the Hand B alterations. In 1594 Heywood published an epyllion Oenone and Paris (strongly influenced by Shakespeare's Venus and Adonis); his Ovidian verse history, Troia Britannica, followed in 1609; his translation of Ovid's Ars Amatoria (stolen and published by another) was not only the first complete English translation but the standard text throughout the seventeenth century; see M.L. Stapleton (ed.), Thomas Heywood's 'Art of Love': The First Complete English Translation of Ovid's 'Ars Amatoria' (Ann Arbor, 2000). Heywood's dealings with the Admiral's Men as actor and playwright appear in R.A. Foakes (ed.), Henslowe's Diary, 2nd edn (Cambridge, 2002), 50, 102, 104, 207, 241, 243. The title-page of his two-part Edward IV (1600) shows that he wrote it for Derby's Men. Heywood was a key member of Worcester's relaunched company from the beginning. With John Duke he stood surety for the company in 1601 for bonds enabling them to play at the Boar's Head and was sued in Chancery when they defaulted; see Herbert Berry, The Boar's Head Playhouse (London and Toronto, 1986), 51-60, 206; with Will Kemp he received payment on behalf of the company for a court performance on 3 January 1602; see PRO Chamber Accounts, quoted by E.K. Chambers, The Elizabethan Stage (Oxford, 1923), 4.167. His play How a Man May Chuse a Good Wife From a Bad As it hath bene sundry times Acted by the Earle of Worcesters Servants was printed in 1602. Foakes, Diary, 213-26 records Heywood's activity as playwright and sharer from August 1602-March 1603. Chambers, Elizabethan Stage, 2.229-32, 236 quotes in full the various documents listing the Queen's Men. Leeds Barroll, Politics, Plague, and Shakespeare's Theater (Ithaca, 1991), 49-59 provides detailed discussion of the interaction of the King's and Queen's Men with the court in 1604. In 1604, Shakespeare's The Merchant of Venice was played at court twice within three days; see W.R. Streitberger (ed.), Collections 13: Jacobean and Caroline Revels Accounts, 1603-1642 (Oxford, 1986), 9; in 1634 Heywood's Love's Mistress; or The Queen's Masque (1636) 'was three times presented before their two Excellent MAIESTIES, within the space of eight dayes', title-page (see also A1-B1).

3 Thomas Dekker, Satiromastix (1602), A3.

4 The English Traveller (1633), A3.

5 Lukas Erne, 'The Popularity of Shakespeare in Print', Shakespeare Survey 62 (2009), 17; Muriel Bradbrook, 'Thomas Heywood, Shakespeare's Shadow', M.T. JonesDavies (ed.), Du Texte à la Scène: Langages du Théâtre (Paris, 1983), 32. 
6 Streitberger, Collections 13, 8.

7 For court performance, see note 2, paragraph 5, above. For residency, see privy council letter to the lord mayor, 31 March 1602, quoted in full in Chambers, Elizabethan Stage, 4.334-5.

8 Other prominent company members included John Duke (ex-Chamberlain's Men player and Heywood's co-defendant in the Boar's Head lawsuit), future theatrical impresario Christopher Beeston, and leading Jacobean and Caroline player Richard Perkins. With both the latter men, Heywood was to maintain a long-term professional relationship stretching into the 1630s. Foakes, Diary, 194, 212-26, 302 records Henslowe's dealings with the company during 1602-3.

9 For Heywood as sharer, see note 2, paragraph 5, above.

10 Carol Chillington Rutter (ed.), Documents of the Rose Playhouse, revised edn (Manchester, 1999), 201-2, argues for the comparatively high spending on 'visual effects' by Worcester's Men. Andrew Gurr, The Shakespearian Playing Companies (Oxford, 1996), 321, suggests this spending 'may simply show the need of a new company to equip itself afresh to work in London' (though they had already been operating there for well over a year), but admits that their recorded outlay of ' $₫ 234$. 11 s. $6 d$ in the seven months with Henslowe [was nevertheless] a good deal more than the Admiral's [Men]' spent over a comparable period.

11 Foakes, Diary, 213-4.

12 Anthony Munday [and others], The first part ... of Sir John Old-castle (1600), A2. Rutter, Documents, 170-1 and Gurr, Playing Companies, 245, reveal a further dimension to this challenge, arguing that the initial commissioning of Oldcastle was itself a response by the Admiral's Men at the Rose to the opening of the Globe. Peter Corbin and Douglas Sedge (eds), The Oldcastle Controversy (Manchester, 1991), 31-3, offer evidence for the ongoing seventeenth-century identification of Shakespeare's character with 'Oldcastle'. Foakes, Diary, 125, 126, 129, 132 (Admiral's Men and Oldcastle); 213, 214, 216 (Worcester's Men and Oldcastle).

13 Foakes, Diary, 224 (payments for the book), 223, 225 (payments for costumes), 21213 (loans to actors riding 'into the contrey $\mathrm{w}^{\text {th }}$ the company to playe'), 225 (recommencement of playing). For plague closure dates see Gurr, Playing Companies, 91-2.

14 For the level of expenditure, see note 10 above.

15 Foakes, Diary, 223.

16 Ibid, 218-19.

17 Thomas Middleton, The Black Book (1604), C3; Thomas Dekker, The Raven's Almanac (1609), F4v, G1v, H1v; John Fletcher, The Night Walker (1640), F2v; Thomas Heywood, The Wise Woman of Hogsdon (1638), E3. 
18 See Wells et al. (eds), Complete Works, 843, for the most recent dating attribution, 'May 1603-April 1604'.

19 The developing application of the proverb, initially used of genuine but misplaced affection, suggests that Shakespeare was the first to apply it to 'a wife' and Heywood the one who popularized this application, with added negative connotations. See, among others, Morris Palmer Tilley, A Dictionary of the Proverbs in England in the Sixteenth and Seventeenth Centuries (Ann Arbor, 1950), 15, 355, and The Oxford Dictionary Of English Proverbs, 3rd edn, rev. F.P. Wilson (Oxford, 1970), 423. Since Fletcher is generally regarded as having used his homage to The Shrew, The Woman's Prize, as a calling-card to the King's Men in 1611, this 1590 s play obviously had continuing currency in the seventeenth century.

20 John Webster, William Rowley, and Thomas Heywood, A Cure for a Cuckold (written and performed 1624, printed 1661); T.J. King, Casting Shakespeare's Plays: London Actors and Their Roles, 1590-1642 (Cambridge, 1992), 76; Ben Jonson, Workes (1616), 72, 176, 438.

21 See especially: Alexander Leggatt, 'Substitution in Measure for Measure', Shakespeare Quarterly 39 (1988), 342-59; Jennifer Panek on Frankford's moral and judicial responsibilities as head of the household, 'Punishing Adultery in A Woman Killed with Kindness', Studies in English Literature 34 (1994), 357-78.

22 Peter Ure, 'Marriage and the Domestic Drama in Heywood and Ford', English Studies 32 (1951), 204; Andrew Gurr, Shakespeare's Opposites: The Admiral's Company 1594-1625 (Cambridge, 2009), 195.

23 Rowland, Heywood's Theatre, 97-154; Panek, 'Punishing Adultery', passim.

24 Arthur Melville Clark, Thomas Heywood: Playwright and Miscellanist (Oxford, 1931), 231.

25 From Matteo Bandello, probably via the version by Geoffrey Fenton, Certain Tragical Discourses (1567), fols 4-36v.

26 'Toe to Toe Across Maid Lane: Repertorial Competition at the Rose and Globe, 1599-1600', Paul Nelsen and Jane Schlueter (eds), Acts of Criticism (Madison, 2006), 21.

27 In a series of recent articles and book chapters but most notably in Rowland, Heywood's Theatre, and his edition of Edward IV (Manchester, 2005).

28 Eleanor Collins, 'Queen Henrietta's Men and the Cockpit Repertory, 1625-1637', $\mathrm{PhD}$ thesis (University of Birmingham, 2009) argues that 'Heywood is, by far, the second most prominent dramatist in the repertory [of Queen Henrietta's Men]' (124) and offers a detailed re-evaluation of the differences between his Red Bull and Cockpit play-texts (107-205). 